\title{
Depositional Setting and Petrophysical Evaluation of Reservoir of the K-Field in the Western Offshore Depobelt, Rio Del Rey Basin, Cameroon
}

\author{
Lionel Takem Nkwanyang1, Olugbenga Ajayi Ehinola², John Eyong Takem³, Ponce Nguema4, \\ Samuel Etame Makoube ${ }^{4}$, Gilbert Mbzighaa Chongwain'1
}

${ }^{1}$ Department of Geology, Pan African University, University of Ibadan, Nigeria

${ }^{2}$ Department of Geology, University of Ibadan, Ibadan, Nigeria

${ }^{3}$ Department of Earth Science, University of Yaounde, Cameroon

${ }^{4}$ Department of Geoscience and Exploration, National Hydrocarbon Cooperation (SNH), Cameroon

Email: ntakem0120@stu.ui.edu.ng

How to cite this paper: Nkwanyang, L.T., Ehinola, O.A., Takem, J.E., Nguema, P., Makoube, S.E. and Chongwain, G.M. (2018) Depositional Setting and Petrophysical Evaluation of Reservoir of the K-Field in the Western Offshore Depobelt, Rio Del Rey Basin, Cameroon. International Journal of Geosciences, 9, 528-546.

https://doi.org/10.4236/ijg.2018.99031

Received: June 28, 2018

Accepted: September 15, 2018

Published: September 18, 2018

Copyright (c) 2018 by authors and Scientific Research Publishing Inc. This work is licensed under the Creative Commons Attribution International License (CC BY 4.0).

http://creativecommons.org/licenses/by/4.0/

\section{c. (i) Open Access}

\begin{abstract}
The Rio Del Rey basin is a prolific petroleum field on the Continental margin of the gulf of Guinea and is one of the major producers in the gulf. The study was carried out using Schlumberger Petrel and Synergy Interactive Petrophysics software for the sequence stratigraphy and petrophysical analysis to study the depositional setting of the Rio Del Rey Basin, using Well Log Data. Five sequence boundaries, five Transgressive Surfaces and four Maximum Flooding Surfaces were identified from wireline log. The progradation of sediments is characterised by a number of stacked sequences deposited in a coastal complex, with offshore, shoreface, beach and tidal deposits. Sequence one contains mostly Lower shoreface deposits of fine to very fine laminated sediments. In sequence two there is, an increase proportion of upper shoreface deposits. Sequence three is dominated by upper shoreface and distributary channels deposits with a concomitant reduction of lower shoreface deposits while sequence four and five contain mostly stack distributary channels and beach deposits. The study has aided the identification and interpretation of two gas bearing and two oil bearing zones in the three wells based on hydrocarbon-typing using the sonic-resistivity logcombination. The total and effective porosities of the reservoirs range from $20 \%$ to $31 \%$ and $15 \%$ to $31 \%$ respectively, indicating that the reservoirs have very good porosities. The ratio of the net to gross thickness of the reservoirs is as high as 0.83 . The water saturation values of the reservoirs ranges from $11 \%-80 \%$. The results of the petrophysical investigation show that the sand formations have good reservoir properties. The vertical facies succession records a migration/translation
\end{abstract}


of laterally linked depositional environment, controlling reservoir properties like geometry, heterogeneity, porosity and permeability.

\section{Keywords}

Sequences, Depositional Environment, Well Logs, Rio Del Rey and Petrophysics

\section{Introduction}

The Rio Del Rey (RDR) Basin of offshore Cameroon is located in the Southwestern portion of Cameroon, in the Southwest Region and is centered in the waters of the Gulf of Guinea. It is bordered to the west and northwest by the Niger Delta and the Calabar flank respectively and to the South by the Rio Muni Basin (Equatorial Guinea). The RDR Basin comprises the easternmost portion of the Niger delta complex [1]. To the North it is bordered by the Rumpi Hills and to the east by the Cameroon Volcanic line (CVL) which separates it from the Douala/Kribi-Campos Basin. The area is located between latitude $8.40 \& 9.00 \mathrm{E}$ and longitude 4.00 and $4.80 \mathrm{~N}$, west of the SSW-NNE CVL (Figure 1). The offshore segment of the Rio Del Rey basin is $7000 \mathrm{~km}^{2}$ and is the main Petroleum producing basin in Cameroon with about $90 \%$ of the country's production while the Douala/Kribi Campo basin produces the rest [2].

Within the Rio Del Ray Basin, is the K-Field which is located in the western offshore depobelt of the Rio del Rey Basin, where sequences of thick clastic material of Agbada Formation were deposited in a deltaic fluvio-marine environment.

The Rio Del Rey Basin is a giant hydrocarbon field that has attracted attention since it's approximately 200 million barrel of proven reserves. Following the first commercial discovery in 1972 within the Ekoundou field, developed by former France Elf Serepca, petroleum exploration and production in the Basin has been on a steady high.

The Rio Del Rey Basin is made up of a high degree of heterogeneity of reservoirs which is associated with the paralic successions of the Agbada formation and this has pose a major problem for geologist to actually analyzed reservoir properties and further estimate hydrocarbon reserves. Deposition of sand in various environment are characterised by different log trends, geometries and dimensions [3]. This shows that the physical characteristics of clastic reservoir rocks reflect a response of the complex interplay of processes operating in a depositional system. Thus, the reconstruction of environments of deposition of these varying clastic successions provides the optimum framework for describing and predicting reservoir quality and distribution [4]. There is also the need to approach the analysis of these sands with more sophisticated interpretation techniques and software's that will enable better understanding of the reservoir 


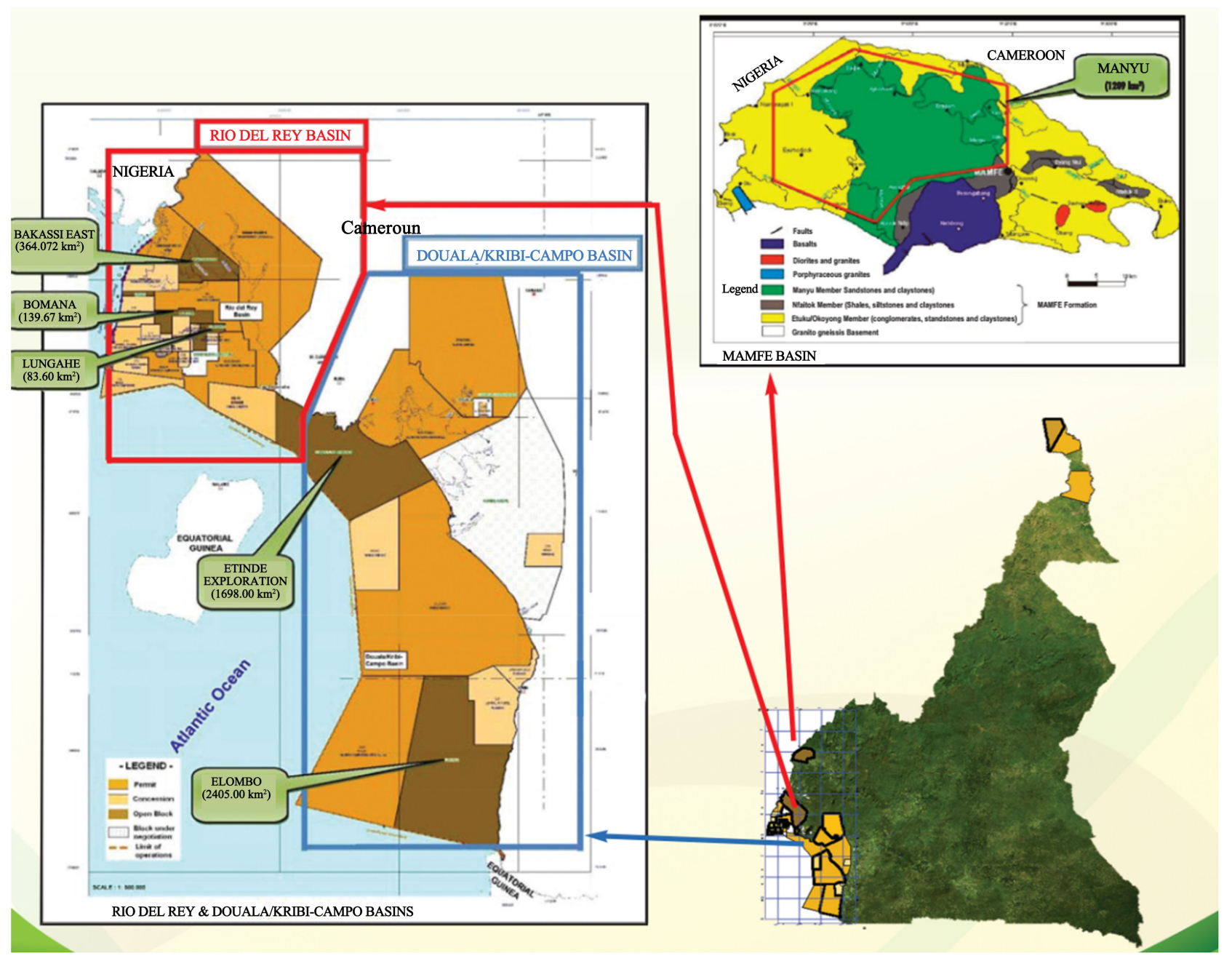

Figure 1. Location map of the Study area [2].

properties so as to reduce uncertainties. This paper presents the results of sequence stratigraphy and petrophysical analysis carried out on the reservoir sands in "Field-K", using the integration of well log facies analysis and petrophysical studies. The environments of deposition of the sands were inferred.

\section{Regional Geology of the Rio Del Rey Basin}

The tectonic and stratigraphic evolutionary history of the Rio del Rey Basin like the other basins lining the West African coast is closely linked with the rifting processes that led to the opening of the South Atlantic, the consequent separation of South America from the African continent and the formation of the Gulf of Guinea. Several authors, have reported on the tectonic processes that started from the Late Jurassic through Early Cretaceous including; the syn-rift sequence (Barremian-Aptian), rift-drift transition phase (mid-late Aptian) and a post-rift phase (Albian-Present) which comprises three stages of drift; Drift I (Albian-oniacian, Drift II (Santonian-Eocene) Drift III (Eocene-Pleistocene).

The clastic sediments of the Niger Delta reach a maximum of $12 \mathrm{~km}$ of thick- 
ness in the core area (Nigeria side), and the stratigraphy is divided into 3 diachronous units from Eocene to Recent age that for a major regressive cycle [5] [6] [7]:

The Rio Del Rey Basin sediments were derived from the ancestral Niger Delta River. Reservoir rocks in K-Field area belong to the Agabda formation and form part of a large N-S prograding systems of Pliocene and Upper Miocene deltaic sandstone, which constitute a long term decreasing accommodation to sediment supply. They are overlain by continental sandstone of Benin formation and overlay marine shales of pro-deltaic Akata formation. The progradation of the sands is characterised by a number of stacked and individually numbered parasequences (Table 1 and Figure 2).

The basin has four structural provinces defined on the basis of deformation types:

The Growth Fault Province in the North: Differential loading of deltaic and continental sediments on underlying prodelta marine shale generated E-W trending syn-sedimentary faults.

The Shale Ridge Province in the Southwest: Overlying loads of deltaic and continental sediments trigger squeeze flow of underlying mobile shale forming mud diapirs (Shale domes, mud volcanoes, shale ridges) within an under compacted and over pressured Shale Formation.

The Delta Toe-Thrust Belt in the South central area: zone of gravity driven compressional/transpressional thrust structures.

The Eastern Province in the Southeast: slightly deformed foreland area juxtaposing the Cameroon Volcanic Line (Figure 3).

\section{Material and Methods}

Well log data from gamma ray, resistivity, density, neutron and sonic logs from three wells in Field-K were used in this study. These logs were acquired from National Hydrocarbon Cooperation in Cameroon (SNH).

Table 1. Summarized stratigraphy of the Rio Del Rey Basin display formation lithology and Environment of deposition.

\begin{tabular}{|c|c|c|}
\hline Main formations & Lithology (age range) & Environment \\
\hline Benin & $\begin{array}{l}\text { Continental massive sands and rare shale interbeds } \\
\text { (Upper Miocene to Recent) }\end{array}$ & $\begin{array}{l}\text { Alluvial and coastal } \\
\text { plain }\end{array}$ \\
\hline Agbada & $\begin{array}{c}\text { Siliciclastic deltaic sequence. Interbeds of } \\
\text { sands and silts designated by "S" and shale } \\
\text { designated by "M" (Upper Miocene to Recent) }\end{array}$ & $\begin{array}{l}\text { Delta front, prodelta, } \\
\text { fluvio-deltaic }\end{array}$ \\
\hline Akata & $\begin{array}{l}\text { Undercompacted marine shales, local } \\
\text { turbiditic sandstones (Nguti, Isongo, } \\
\text { Oongue), channel fill or offshore bar deposits } \\
\text { (Etisah, Qua Iboe, Rubble beds ...) } \\
\text { (Palaeocene to Recent) }\end{array}$ & Prodelta, Deepwater \\
\hline
\end{tabular}




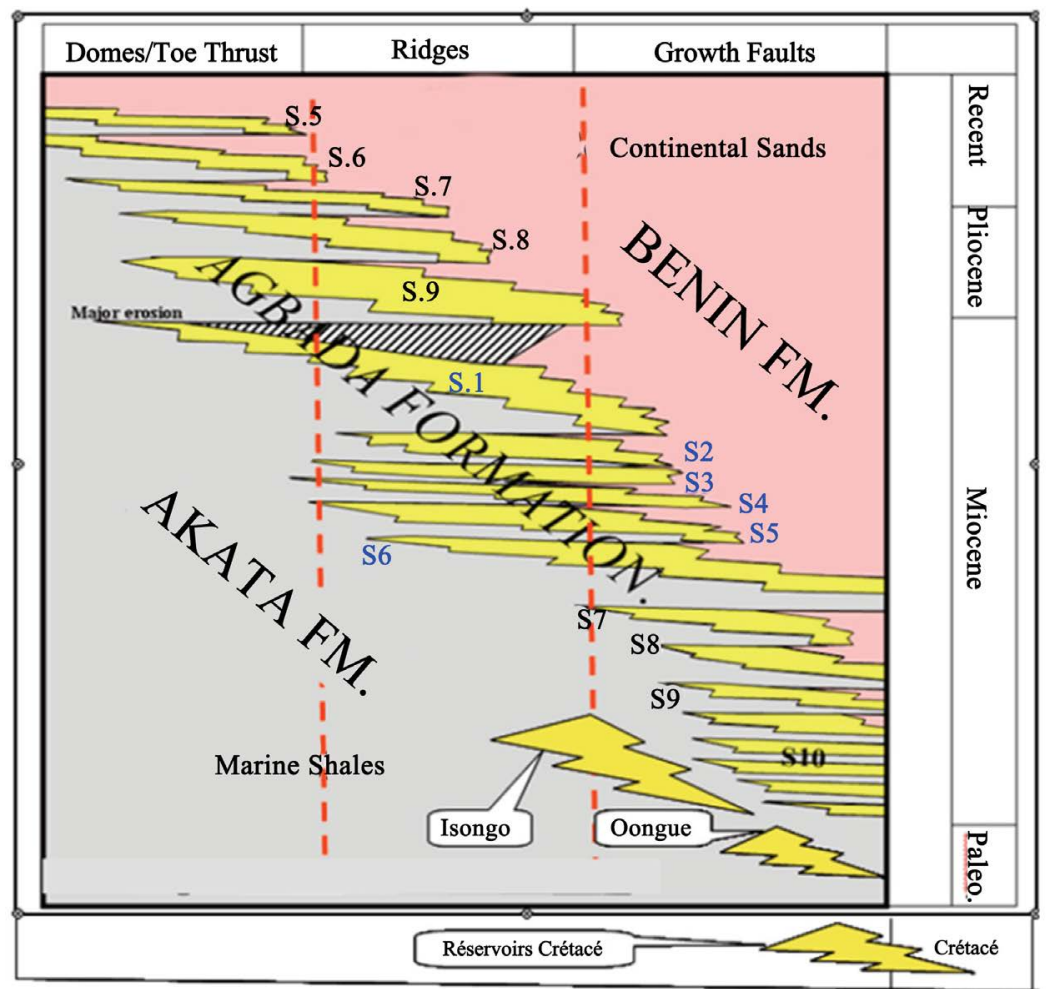

Figure 2. Schematic stratigraphic section of the Rio Del Rey basin, Offshore Cameroon [8].

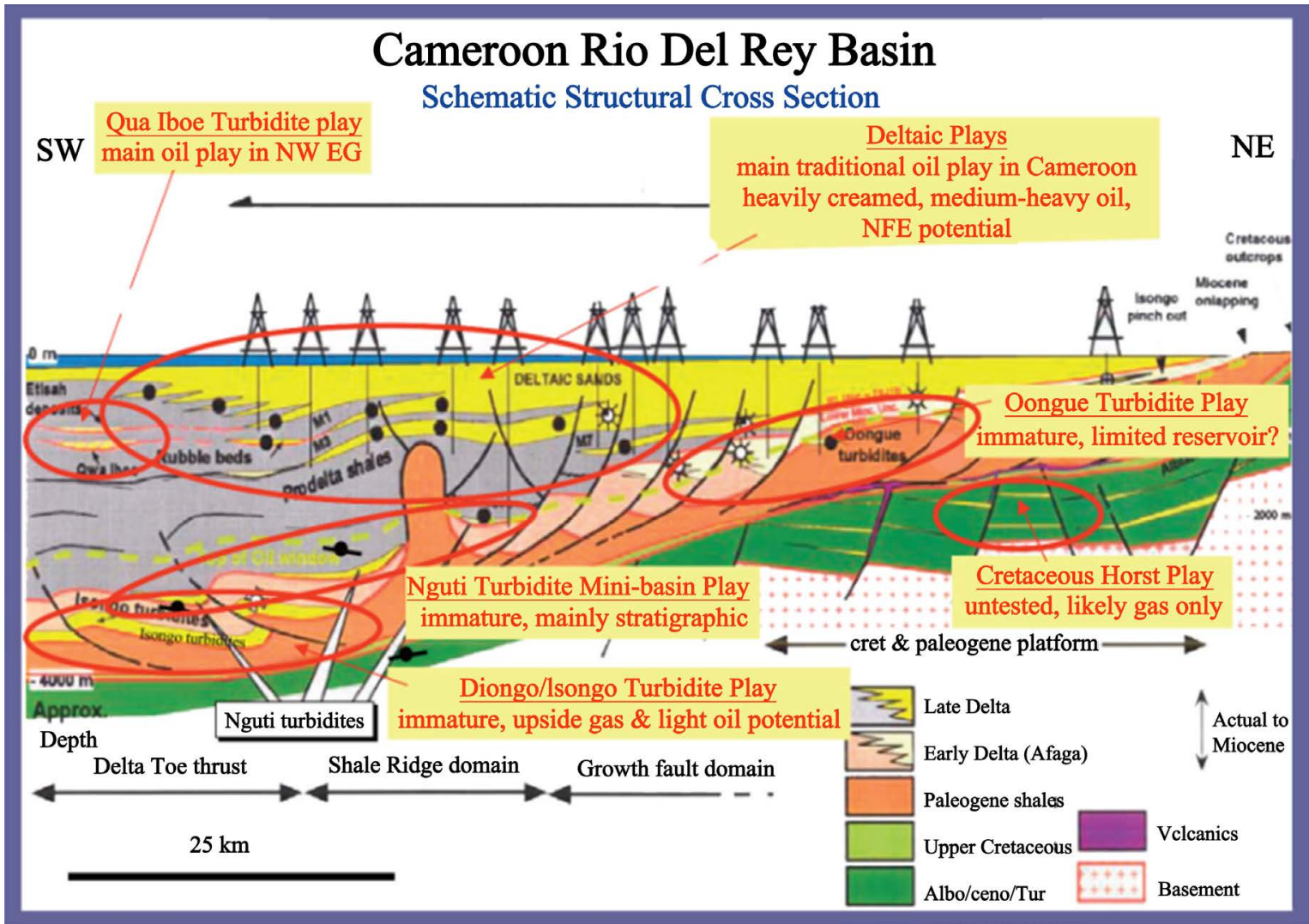

Figure 3. Rio Del Rey Basin structural setting [8]. 
Wireline log patterns (GR and RT) and shapes were determined and used to predict lithology and depositional environment. The depositional environments of the wells were delineated using sequence stratigraphic principles ([9] [10]) from which petrophysical parameters were calculated (Figure 4).

In this study, well logs were subjected to detailed qualitative and quantitative analyses by means of the Interactive Petrophysics (IP) software. The software consists of separate programs for reliable interpretation of all petrophysical characteristics including environmental corrections, statistical, petrophysical, and lithological analyses using a number of equations, empirical relations, and charts. The hydrocarbon potential evaluation is based on the petrophysical analysis, including determination of the reservoir properties such as porosity, permeability, oil and water saturations, and the movable oil within theclastic rocks and interpretation of lithological and mineralogical components. The lithology and mineralogy components of the clastic rocks were investigated using Schlumberger charts formulas on IP such as neutron-density and M-N cross-plots.

Shale volumes in reservoirs were evaluated using GR curves by applying "Larionov Tertiary Rock" method. GR curves were used in the evaluation because all the three wells have GR curves; very few of them have Neutron/Density pair. Larionov method was chosen because it goes well with Tertiary Rio del ray Basin rocks and is widely used in the industry. The applied equations are shown below:

Volume of Clay from Neutron/Density crossplot

$$
\begin{aligned}
& V c l N D= \\
& \frac{(\operatorname{DenC} / 2-\operatorname{DenC} / 1) \times\left(\mathrm{Neu}-\frac{\mathrm{NeuC}}{1}\right)-\left(\mathrm{Den}-\frac{\mathrm{DenC}}{1}\right) \times\left(\frac{\mathrm{NeuC}}{2}-\frac{\mathrm{NeuC}}{2}\right)}{(D e n C} \\
& \overline{\left(\frac{\operatorname{Den} C}{2}-\frac{\text { DenC }}{1}\right) \times\left(\text { NeuClay }-\frac{N e u C}{1}\right)-\left(\text { DenClay }-\frac{\text { DenC }}{1}\right) \times\left(\frac{N e u C}{2}\right)}
\end{aligned}
$$

\section{Volume of clay from Gamma ray (Oil reservoirs)}

$$
V c l G r=\frac{G r-G r C l e a n}{\text { GrClay }- \text { GrClean }}
$$

\section{Larionov younger rocks (Tertiary clastics)}

$$
V c l G r=0.08336\left(2^{3.7 \times Z}-1\right)
$$

\section{Volume of clay from Resistivity (Gas reservoirs)}

$$
V c l R t=\frac{R \text { clay }}{R t} \times \frac{(\text { Rclean }-R t)}{(\text { Rclean }- \text { Rclay })}
$$

The porosity and water saturation interpretation module on IP is used to interactively calculate porosity (PHI), water saturation (SW), flushed zone water saturation (SXO), matrix density (RHOMA), hydrocarbon density (RHOHY), and wet and dry clay volume (VWCL and VDCL). A temperature value that ranges from $67^{\circ} \mathrm{C}$ to $112^{\circ} \mathrm{C}$ within the reservoirs was provided as part of the data suit. Total porosity was estimated majorly from initial porosity models such as 


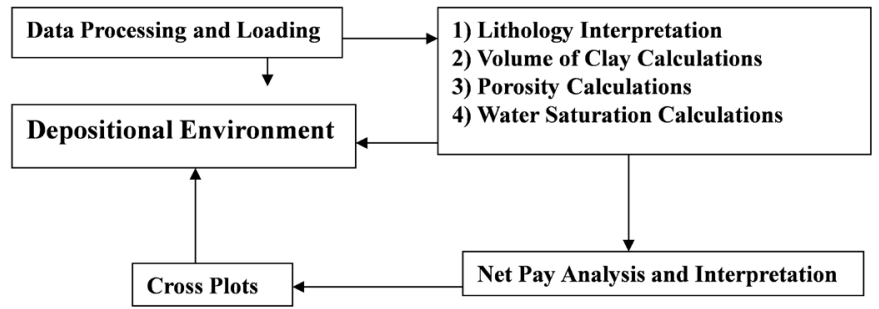

Figure. 4. A flow chart showing the main steps of a standard petrophysical log analysis and well log pattern to delineate environment of deposition.

density/neuron, density, neutron, and sonic logs. The effective porosity was then deduced by introducing shale volume into the equation. Water saturation was estimated from Archie's and Modified Simandoux equations. The equations used are highlighted below

$$
\begin{array}{cr}
S w=\sqrt[n]{\frac{(a \times R w)}{R t \times P h i e^{m}}} & \text { Archie } \\
\frac{1}{R t}=\frac{\varnothing^{m} \times S w^{n}}{a \times R w \times(1-V c l)}+\frac{V c l \times S w}{R c l} & \text { Modified Simandoux }
\end{array}
$$

The uninvaded zone's water saturation (Sw) determined by Archie equation is one of the most fundamental parameters in log evaluation because it also help to determined hydrocarbon movability when combined with water saturation of the flushed zone (Sxo).

Since core data was not available for the reservoir, empirical calculation was used to predict permeability in the reservoir. Morris Biggs gas and oil was employed in this study for that purpose. The equations is stated below

$$
\mathrm{K}=a \cdot \frac{P h i^{b}}{S w i^{c}}
$$

Cut-off values were established for the following answer curves based on experience in the Rio del Rey Basin and the general data trend: volume of clay $(V c l)$, effective porosity (Phie) and water saturation $\left(S_{W}\right)$. The cut-off values adopted are 0.4, 0.1 and 0.5 respectively. Pay zones were delineated on the basis of these cut-off values. Sums and averages were determined using the previously defined net reservoir counts. Based on log interpretation, curves were constructed. These curves were used as discriminators to calculate sums and averages for the reservoir.

\section{Results and Discussion}

\subsection{Sequence Analysis}

A lithostratigraphic interpretation of key wells along K-field served as a basis for sequence stratigraphic analysis. Three wells (A5, A4 and A3) with composite logs (spontaneous potential, SP, gamma-ray, GR, sonic, DT or LDT, and density, Rhob) were available offshore, and no well was available onshore. The age of the basement in the offshore Rio Del Rey Basin is unknown as it has not been pene- 
trated by any wells. However from field studies and other internal report with onshore well, the basement is expected to comprise Precambrian conglomerates, sandstones, limestones and claystones with volcanic rocks and granitic intrusions [11].

Well logs sequence stratigraphy analysis of Benin and Agbada formations was performed to ensure robust correlations of depositional packages to develop more detailed framework for reservoir correlation. Interpreted facies association defined a good framework for genetic stratigraphic sequence [12] method, where maximum flooding surfaces (MFS) defined as sequence boundaries (Figure 5).

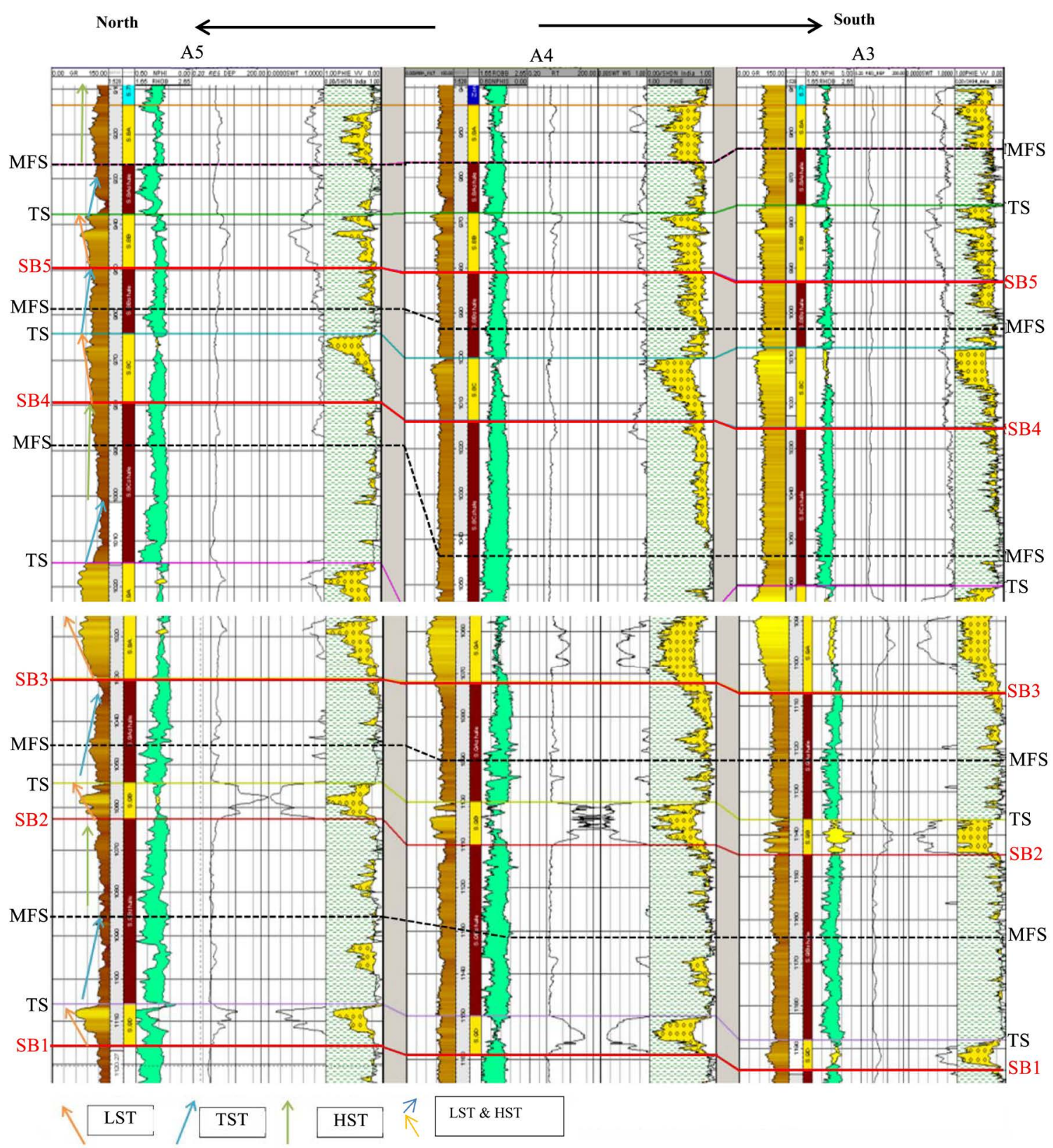

Figure 5. Lithostratigraphic correlation (sonic, gamma and density logs) along a S-N. Log patterns show overall upward coarsening trends and general decrease in sequence thickness upward. 
Lowstand, trangressive, highstand system tract, and maximum flooding surfaces were picked and correlated between the wells.

\subsubsection{Sequence 5}

This sequence is bounded by SB5 and MFS4 and has a thickness of up $350-400$ $\mathrm{m}$. The interval consists of two higher order component of fluvio-deltaic lithosomes defines an overall progradational stacking pattern or regressive structure, which is splited by Transgressive surface (TS). This sequence consists mostly of sand deposited from suspension under wised known as sandy Benin Formation. The sandy sediments also contain isolated thin muddy beds deposited during storms when the wave base extends downward and seaward. The shoreface extend between the fair weather wave base and the intertidal zone and forms a relatively steep concave-upward profile [4]. The shoreface upward coarsening profile is controlled by wave action. The lower shoreface or distal portion is composed of very fine to fine sand deposited by storm currents. These deposits are usually heavily bioturbated by open marine Cruiziana ichnofacies, which effectively decreases porosity and permeability.

\subsubsection{Sequence 4}

This sequence is bounded by SB4 and MFS3 and has a thickness of up $180-200$ $\mathrm{m}$. This sequence dominated by Upper shoreface and estuarinefacies interval. However, in well A4 this sequence represented by shoreface to pro-delta facies with turbidite units. Thickness variations of sandy packages can be related to the preexisting basin topography, where delta progrades into the basin that formed due to extension. Sequence four interpreted as upper shoreface, distributary and estuarine channels have a fining-upward to blocky profile. Systems tractshows an abrupt basinward shift indicating a change in depositional pattern from progradation to aggradation. The HST is well developed in the distal platform but it is much reduced in the continental area where it is represented by a condensed interval

\subsubsection{Sequence 3}

This sequence is limited by SB3 and MFS2 with TS2 in between and has thickness up to $400-450 \mathrm{~m}$. Mid Agbada sequence is very complex part of the succession and it has several higher order stacked deltaic parasequences. The general profile is prograding to retrograding. Prograding segment is dominated by delta-front and shoreface deposits with thin distributory plain facies intervals. Retrogradational segment is dominated by estuarine and shorefacefacies, also with thin delta plain facies intervals. Prograding segment indicates regression, but the bottom part of sequence represented by normal regression (well A5 and A4) and forced regression (well A3). Retrograding segments indicating relatively slow transgression period and more pronounced in the distal section of well A5 and A4, while they shows more aggradational feature in the West of well A5upper section. Moreover, on the bottom part of this sequence in well A3 retrograding parasequence represented in form of the sharp transition to prograding parase- 
quence, while it is more gradual in well A4. Sandy packages are thicker and more homogeneous on the western section of the well.

\subsubsection{Sequence 2}

This sequence bounded by SB2 and MFS1 and has a thickness up to $190-200 \mathrm{~m}$. There is a missing stratigraphic intervals in the upper part of this succession that caused by erosion. The general profile of this succession is retrogration with relatively thin layer of prograding segment at the bottom. Prograding segment is dominated by stacked distributary channels, and retrograding segment is represented with minor amount of beach deposits and thin layer of Estuarinefacies. In general, the Miocene is characterized by retrogradational patterns indicating a Transgressive phase with deposition of hemi-pelagic sediments.

\subsubsection{Sequence 1}

This sequence bounded by SB1 and TS1 and has a thickness up to $150-200 \mathrm{~m}$. Three systems tracts were defined in this sequence, TST and HST and LST (Figure 5), however on the upper part of the sequence in well A3 there is an evidence of forced regression. The prograding sequence started from deposition of shelfal to pro-delta units that dominated by thick turbidite lobes, and followed by deposition of deltaic to shoreface units. The retrograding segment represented by shoreface units with thin layer of estuarine units. Sandy packages are thicker on the A4 well.

In all cases depositional facies logs (Shale, Upper Shore, Lower Shoreface, and Channels) were created for each sequence, based on gamma ray profile and shale content using the neutron density log separation, Shoreface is characterised by an upward coarsening profile, while channels have fining upward to blocky profile in the gamma ray. Upper Shoreface is differentiated from the Lower Shoreface deposits by it low shale content (Little or no separation between the neutron density porosities) and it position on top of the sequence, while lower Shoreface are heterolithic (alternation of sand and clay) in the lower part of the sequence. Overall sand thicknesses are higher to the south and decreases northward (distal portion of the coastal complex).

\subsection{Petrophysical Evaluations}

The evaluated log interval (1000 m to $2500 \mathrm{~m}$ ) for Well-A3, A4 and A5 has two major lithological units based on gamma ray log, and neutron-density lithology plot, namely: shale and sandstone. A cut off value of 73API was determined using the gamma ray log values, below it are reservoirs while those above it are shale. The shales act like seals to the reservoir rocks (sandstone) that accommodate the hydrocarbons and water in the basin. In this deltaic formation, the geological sequence predominantly consists of sandy formation, which is continuous in most cases from the top to the bottom with alternating occurrence of clay and shale layers. Fifteen reservoirs were delineated with different thicknesses, but six (6) of them are of interest to this study, because of their thickness 
and fluid saturation type. These reservoir bodies were marked as Zone- $R_{1}$ to $R_{15}$ (Tables 2-4).

\subsubsection{Well A3}

The results of the petrophysical evaluations show that four of the nine delineated reservoirs in A3 well contain hydrocarbons. Reservoirs $R_{2}$ and $R_{4}$ contain gas, while reservoir $R_{6}$ and $R_{8}$ contains oil. This sandstone bed has an average shale volume of 0.11 to 0.14 , which is below the limit of $15 \%$. The calculated average reservoir porosity is 0.271 to 0.31 and average water saturation of 0.34 to 0.4 , with hydrocarbon saturation 0.54 to 0.56 (54\% to 56\%) (Table 2). The effective porosity is also very good ( 0.23 to 0.29 ), due to little shale effect. An average permeability of 46.12 to $865 \mathrm{md}$ was calculated for this reservoir, which is good enough to permit free flow of fluid. According to Rider (1986) porosity and

Table 2. Average petrophysical parameters for reservoir in A3 Well.

\begin{tabular}{|c|c|c|c|c|c|c|c|c|c|c|c|}
\hline $\begin{array}{c}\text { Reservoir } \\
\text { Unit }\end{array}$ & Top (m) & Base (m) & $\begin{array}{c}\text { Gross } \\
\text { thickness (m) }\end{array}$ & $\begin{array}{l}\text { Net thickness } \\
\text { (m) }\end{array}$ & $\mathrm{N} / \mathrm{G}$ & $\begin{array}{l}\mathrm{A}_{\mathrm{v}} \mathrm{V}_{\mathrm{cl}} \\
(\mathrm{v} / \mathrm{v})\end{array}$ & $\begin{array}{c}\mathrm{A}_{\mathrm{v}} \mathrm{P}_{\mathrm{hi}} \mathrm{E} \\
(\mathrm{v} / \mathrm{v})\end{array}$ & $\begin{array}{l}\mathrm{A}_{\mathrm{v}} \mathrm{K} \\
(\mathrm{md})\end{array}$ & $\begin{array}{l}A_{v} S_{w} \\
(v / v)\end{array}$ & $\begin{array}{l}A_{v} S_{h} \\
(v / v)\end{array}$ & $\begin{array}{l}\text { Fluid } \\
\text { type }\end{array}$ \\
\hline $\mathrm{R}_{1}$ & 1521.87 & 1630.53 & 108.66 & 0.00 & 0.00 & & - & - & - & - & - \\
\hline $\mathrm{R}_{2}$ & 1630.53 & 1695.45 & 64.92 & 17.68 & 0.272 & 0.129 & 0.293 & 234.56 & 0.470 & 0.53 & Gas \\
\hline $\mathrm{R}_{3}$ & 1695.45 & 1865.38 & 169.93 & 47.48 & 0.279 & 0.114 & 0.244 & 112.70 & 0.760 & 0.24 & Water \\
\hline $\mathrm{R}_{4}$ & 1865.38 & 1909.11 & 43.73 & 33.60 & 0.768 & 0.118 & 0.276 & 865.75 & 0.413 & 0.58 & Gas \\
\hline $\mathrm{R}_{5}$ & 1909.11 & 1922.83 & 13.72 & 11.05 & 0.805 & 0.112 & 0.229 & 99.23 & 0.940 & 0.06 & Water \\
\hline $\mathrm{R}_{6}$ & 1922.83 & 1940.97 & 18.14 & 10.82 & 0.597 & 0.146 & 0.236 & 196.34 & 0.347 & 0.65 & Oil \\
\hline $\mathrm{R}_{7}$ & 1940.97 & 1947.82 & 6.85 & 1.29 & 0.189 & 0.134 & 0.244 & 44.67 & 0.869 & 0.13 & Water \\
\hline $\mathrm{R}_{8}$ & 1947.82 & 1967.79 & 19.97 & 7.62 & 0.382 & 0.147 & 0.234 & 94.50 & 0.408 & 0.59 & Oil \\
\hline $\mathrm{R}_{9}$ & 1967.79 & 2121.41 & 153.62 & 0.76 & 0.005 & 0.188 & 0.277 & 60.72 & 0.984 & 0.02 & Water \\
\hline
\end{tabular}

N/G net to gross, Av Vcl average volume of clay, Av Phi E average effective porosity, Av K average permeability, Av Sw average water saturation, Av Sh average hydrocarbon saturation, - Absent of data.

Table 3. Average petrophysical parameters for reservoir in A4 Well.

\begin{tabular}{|c|c|c|c|c|c|c|c|c|c|c|c|}
\hline $\begin{array}{c}\text { Reservoir } \\
\text { Unit }\end{array}$ & Top (m) & Base (m) & $\begin{array}{c}\text { Gross } \\
\text { thickness }(\mathrm{m})\end{array}$ & $\begin{array}{l}\text { Net thickness } \\
(\mathrm{m})\end{array}$ & $\mathrm{N} / \mathrm{G}$ & $\begin{array}{l}\mathrm{A}_{\mathrm{v}} \mathrm{V}_{\mathrm{cl}} \\
(\mathrm{v} / \mathrm{v})\end{array}$ & $\begin{array}{c}\mathrm{A}_{\mathrm{v}} \mathrm{P}_{\mathrm{hi}} \mathrm{E} \\
(\mathrm{v} / \mathrm{v})\end{array}$ & $\begin{array}{l}\mathrm{A}_{\mathrm{v}} \mathrm{K} \\
(\mathrm{md})\end{array}$ & $\begin{array}{l}A_{v} S_{w} \\
(v / v)\end{array}$ & $\begin{array}{l}A_{v} S_{h} \\
(v / v)\end{array}$ & $\begin{array}{l}\text { Fluid } \\
\text { type }\end{array}$ \\
\hline $\mathrm{R}_{16}$ & 279.81 & 745.39 & 465.58 & 0.00 & 0.000 & - & - & - & - & - & - \\
\hline $\mathrm{R}_{17}$ & 745.39 & 1157.00 & 411.61 & 397.74 & 0.966 & 0.112 & 0.399 & 773.44 & 0.203 & 0.797 & Oil \\
\hline $\mathrm{R}_{18}$ & 1157.00 & 2004.97 & 847.97 & 24.65 & 0.028 & 0.253 & 0.335 & 343.04 & 0.944 & 0.056 & Water \\
\hline
\end{tabular}

Table 4. Average petrophysical parameters for reservoir in A5 Well.

\begin{tabular}{ccccccccccccc}
\hline $\begin{array}{c}\text { Reservoir } \\
\text { Unit }\end{array}$ & Top $(\mathrm{m})$ & Base $(\mathrm{m})$ & $\begin{array}{c}\text { Gross thickness } \\
(\mathrm{m})\end{array}$ & $\begin{array}{c}\text { Net thickness } \\
(\mathrm{m})\end{array}$ & $\mathrm{N} / \mathrm{G}$ & $\begin{array}{c}\mathrm{A}_{\mathrm{v}} \mathrm{V}_{\mathrm{cl}} \\
(\mathrm{v} / \mathrm{v})\end{array}$ & $\begin{array}{c}\mathrm{A}_{\mathrm{v}} \mathrm{P}_{\mathrm{hi}} \mathrm{E} \\
(\mathrm{v} / \mathrm{v})\end{array}$ & $\begin{array}{c}\mathrm{A}_{\mathrm{v}} \mathrm{K} \\
(\mathrm{md})\end{array}$ & $\begin{array}{c}\mathrm{A}_{\mathrm{v}} \mathrm{S}_{\mathrm{w}} \\
(\mathrm{v} / \mathrm{v})\end{array}$ & $\begin{array}{c}\mathrm{A}_{\mathrm{v}} \mathrm{S}_{\mathrm{h}} \\
(\mathrm{v} / \mathrm{v})\end{array}$ & $\begin{array}{c}\mathrm{F}_{\text {Fluid }} \\
\text { type }\end{array}$ \\
\hline $\mathrm{R}_{19}$ & 103.02 & 960.60 & 857.58 & 0.000 & 0.000 & - & - & - & - & - & - \\
$\mathrm{R}_{20}$ & 960.60 & 1355.60 & 395.00 & 163.43 & 0.414 & 0.145 & 0.278 & 178.24 & 0.431 & 0.569 & Oil \\
$\mathrm{R}_{21}$ & 1355.60 & 1786.13 & 430.53 & 0.000 & - & - & - & - & - & - & - \\
\hline
\end{tabular}


permeability classification, the porosity and permeability are classified as "very good'. The crossover log pattern of density and neutron log and the high value of true resistivity, show that the reservoir $\mathrm{R}_{2}$ and $\mathrm{R}_{4}$ are entirely a gas-reservoir. Added to the neutron-density crossover pattern, neutron-density plot indicates that the reservoir is gas-bearing sandstone, as the points plot to the left of the clean water-bearing sandstone line Figure 6 [13].

\subsubsection{Well A4}

Contain a huge sandstone reservoir bed with a thickness of $397.74 \mathrm{~m}$ and occurs at a depth interval of $745.39 \mathrm{~m}$ and $1157 \mathrm{~m}$ that contain hydrocarbon of the three reservoirs delineated. It has an average shale volume of 0.11 (11\%), which is below the limit of $15 \%$ (Table 3). This reservoir has an average porosity of 0.36 , which according to [14] classified; it is "excellent". This zone has low average water saturation (0.203), with very high average hydrocarbon saturation (0.797). Averagely, this reservoir has permeability of $773 \mathrm{md}$, which can permit a very free flow of fluid. According to [14] permeability classification, this permeability is classified as "excellent". At this reservoir zone, density curve reads much higher porosity (0.8) and aligned with the neutron log- "no crossover" [15], combined with the neutron density plot (Figure 7) and with average true resistivity values, there is all indicating that the zone is entirely an oil-bearing sandstone reservoir.

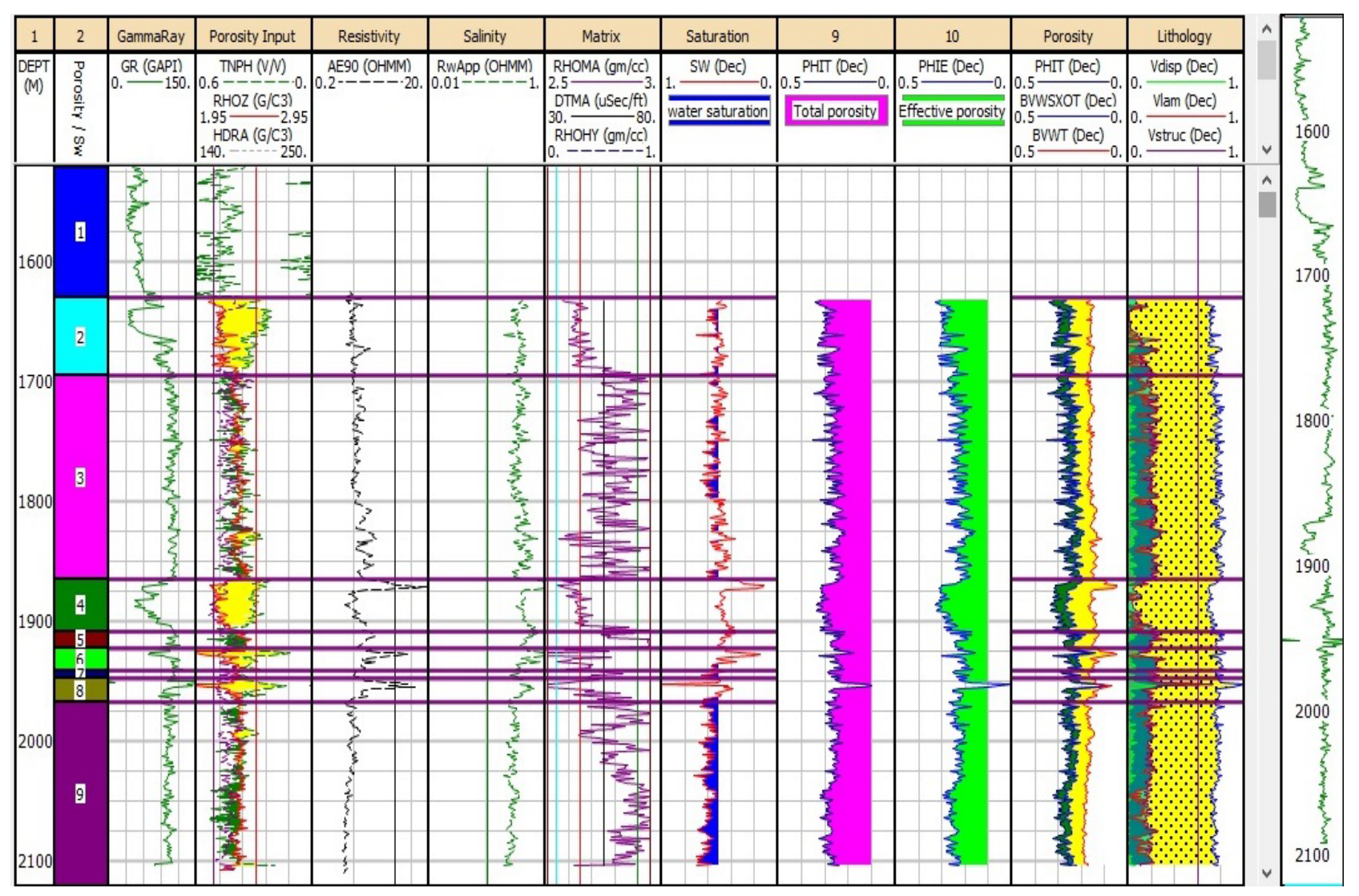

Figure 6. Estimated porosity water saturation and fluid type in Well A3. 


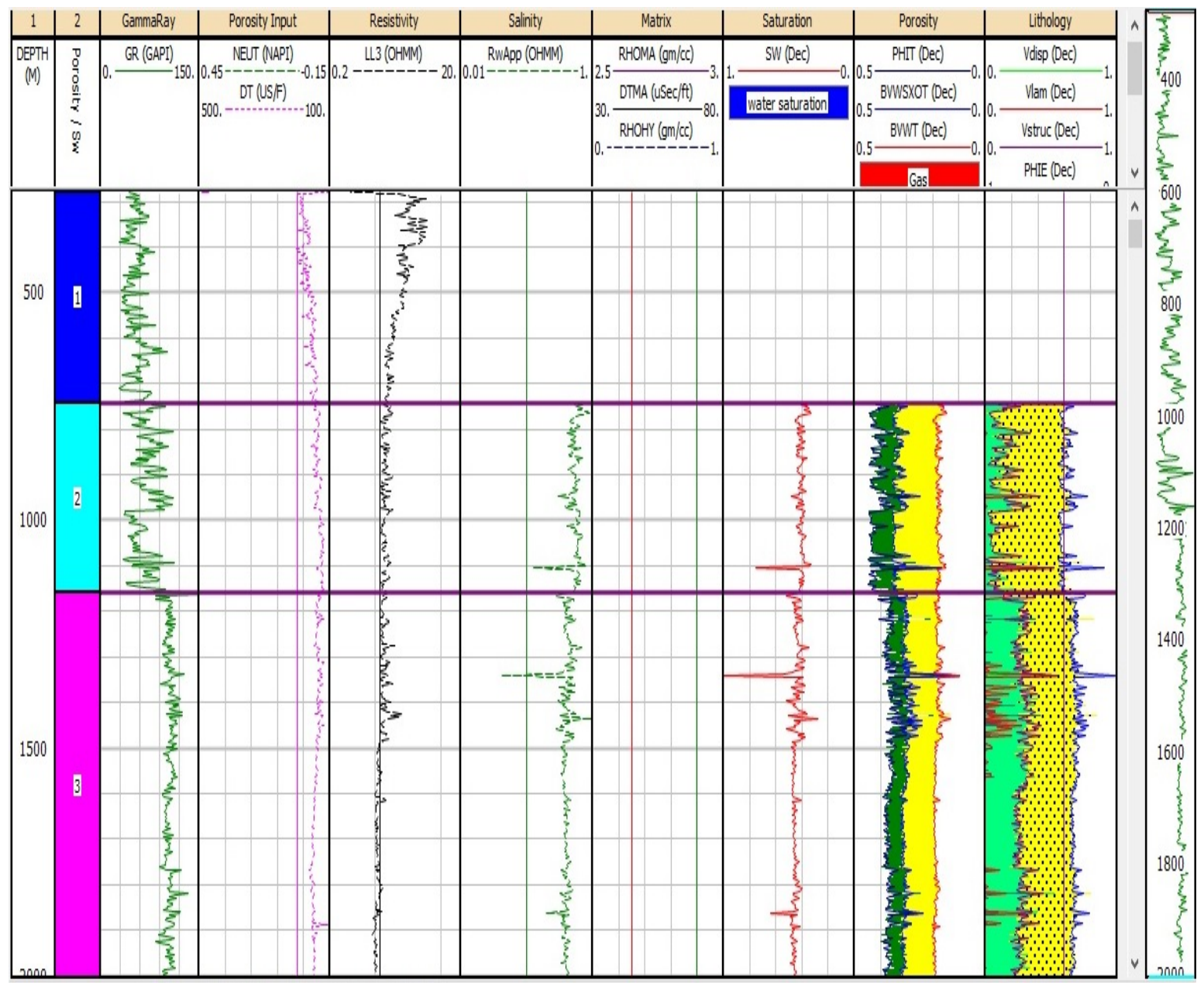

Figure 7. Estimated porosity, water saturation and fluid types present in A4 well.

\subsubsection{Well A5}

Contain one reservoir at a depth interval of $960.60 \mathrm{~m}$ and $1355.60 \mathrm{~m}$, with a thickness of $395 \mathrm{~m}$. It has an average porosity of 0.27 . These porosities are very good according to [14] porosity classification. This reservoir has an average shale volume of $0.14(14 \%)$, which is a little bit below the limit of $15 \%$ that can affect water saturation and free flow of fluid. This reservoir has average water saturation (0.431), with average hydrocarbon saturation (0.569). This reservoir has an average permeability of $735.75 \mathrm{md}$, which is excellent permeability for fluid flow. The computed petrophysical parameters for this reservoir are presented in Table 4 (Figure 8).

\subsection{Lithological Interpretation with Cross-Plots}

Lithology and mineralogy components of rocks in K-Field were interpreted through different cross-plots (Figure 9 and Figure 10) where different types of matrix appear by combining different well logs.

\subsubsection{Neutron (NPHI) vs. Density (RHOB) Cross-Plot}

The cross-plot of neutron (NPHI) versus density (RHOB) shows that the rock 
appears to be composed mainly of shale with intercalated sandstone as well as carbonates (limestone) as shown in Figure 9(a). The limestone content is generally low as illustrate on the limestone line (Figure 11(a)).

\subsubsection{M-N Cross-Plots}

The M-N cross-plots reveal the same interpretation and reflect that the majority of the points are mainly shale except in A3 reservoir, while other points suggest the existence of the carbonates (Figure $9(\mathrm{~b})$ ). The M-N cross plot can also be used to investigate the secondary porosity associated with the lithology (Figure 9(a)). This secondary pore type may be attributed to the partially or completely dissolution of the presence of significant amount of carbonate cements. The dissolution of the carbonate cements within the Early Cretaceous sandstone reservoir has been reported by [16].

\subsubsection{Buckles Plot}

Buckle plot shows that majority of the points in well A3 (Figure 10(a)) cluster around a BVW hyperbolic curve, slightly below 0.06 value curve, but the others
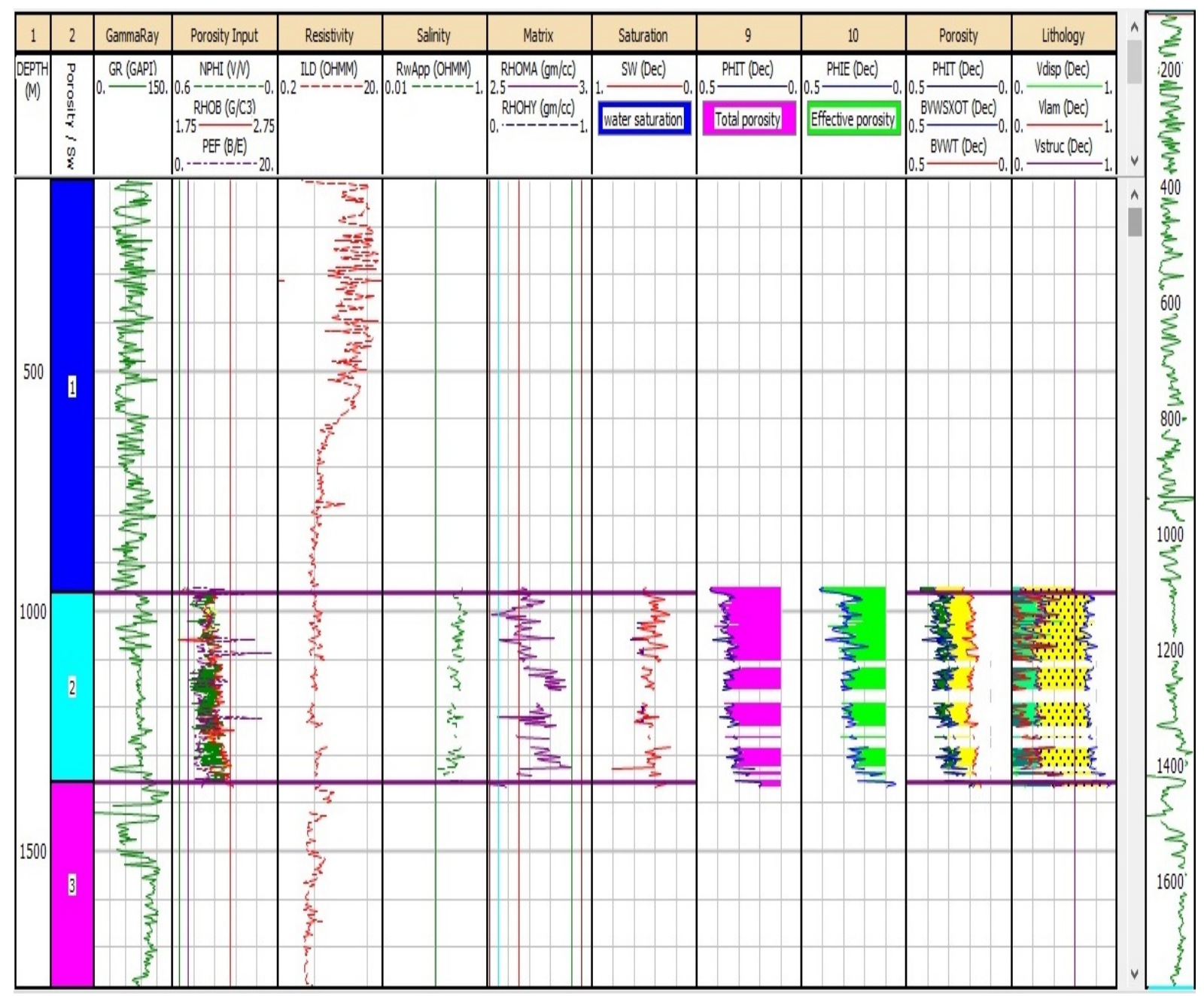

Figure 8. Estimated porosity, water saturation and fluid types present in A5 well. 


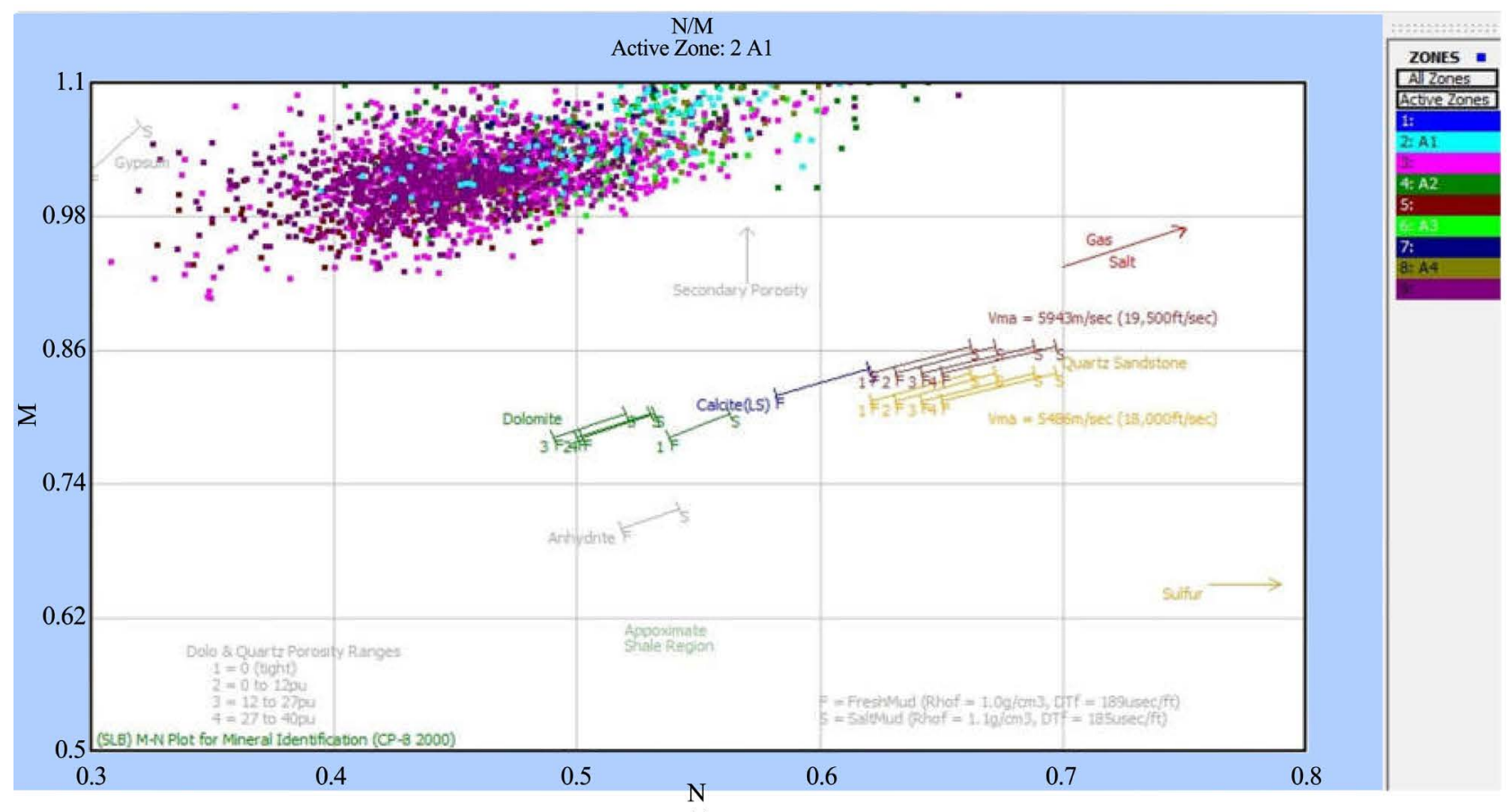

(a)

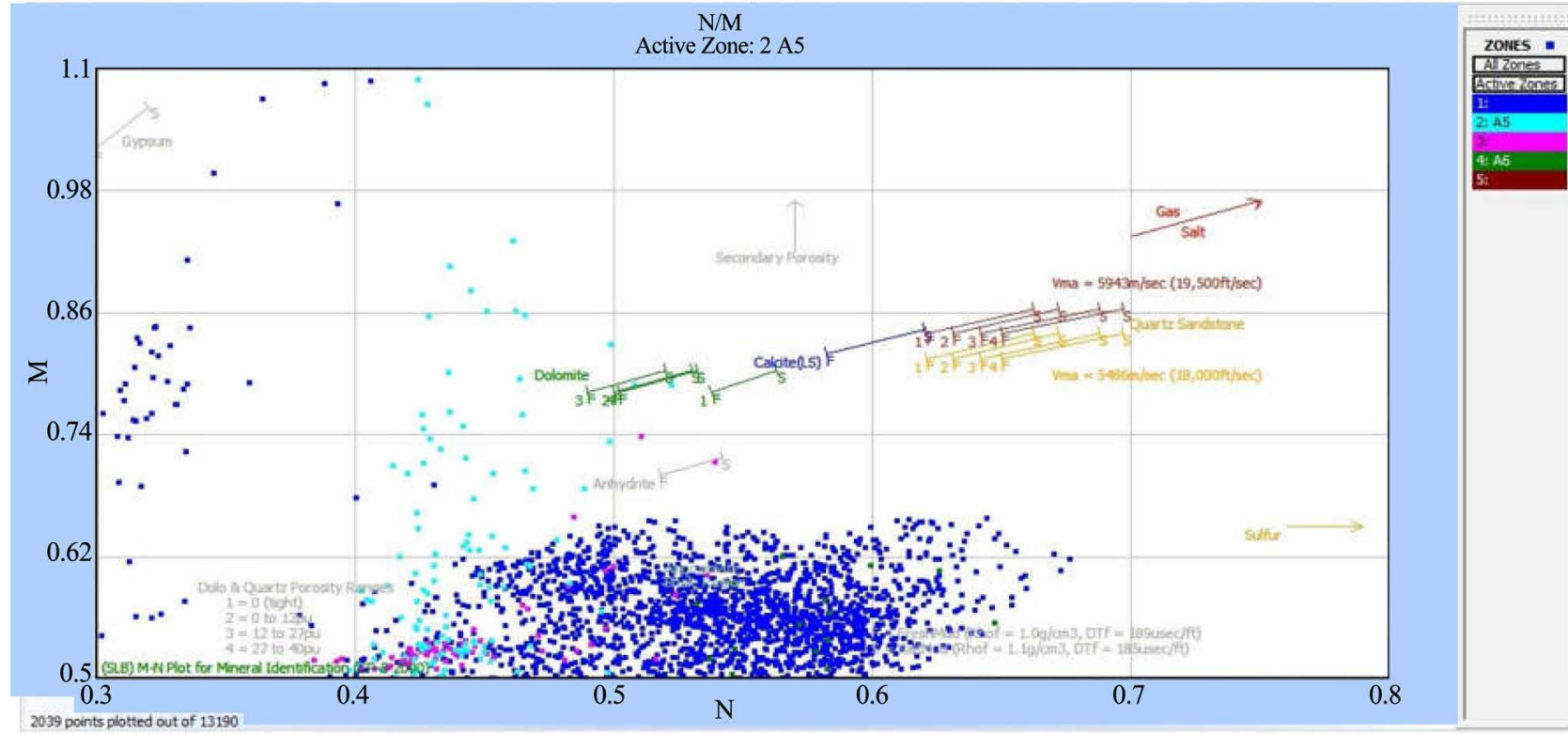

(b)

Figure 9. M-N cross-plot showing lithological components of reservoir rocks in the studied wells at K-Field with (a) well A3 and (b) well A4.

are scattered at higher values of BVW, indicating movable water (reservoir $\mathrm{R}_{4}$, $\mathrm{R}_{6}$ ). The scattered pattern of the point in the Buckles plot (Figure 10(b)) indicates that the zone is not at irreducible water saturation, and therefore, water will be produced because the formation has more water than it can hold by capillary pressure. Reservoir $R_{2}, R_{8}$ indicate hydrocarbon saturation at irreducible water saturation, the points plot around a particular BVW hyperbolic curve (Figure 10(a)) thus indicating that hydrocarbon can be produce from this re- 
servoir with little or no water [17].

\section{Conclusion}

The vertical facies succession records a migration and translation of laterally linked depositional environment controlling reservoir properties like geometry (thickness and lateral extensions), heterogeneity, porosity and permeability. Reservoir properties in well A5, A4, and A3 are linked to the facies properties in a flood stage known as depositional controls. Delta plain, shoreface and channels deposits are the best reservoir quality rocks, whereas very fine grain sized fluvial floodplain deposits have lower quality reservoir properties. Delta front and channel deposits have the thickest facies with a minimum of up to $28 \mathrm{~m}$. Water saturations in reservoir $R_{4}, R_{6}$, and $R_{8}$ are very good ranging between $5 \%$ and $15 \%$ while very poor in some other reservoirs as high as $100 \%$. The reservoir temperature ranges between $160^{\circ} \mathrm{C}-166^{\circ} \mathrm{C}$ which shows that the reservoir
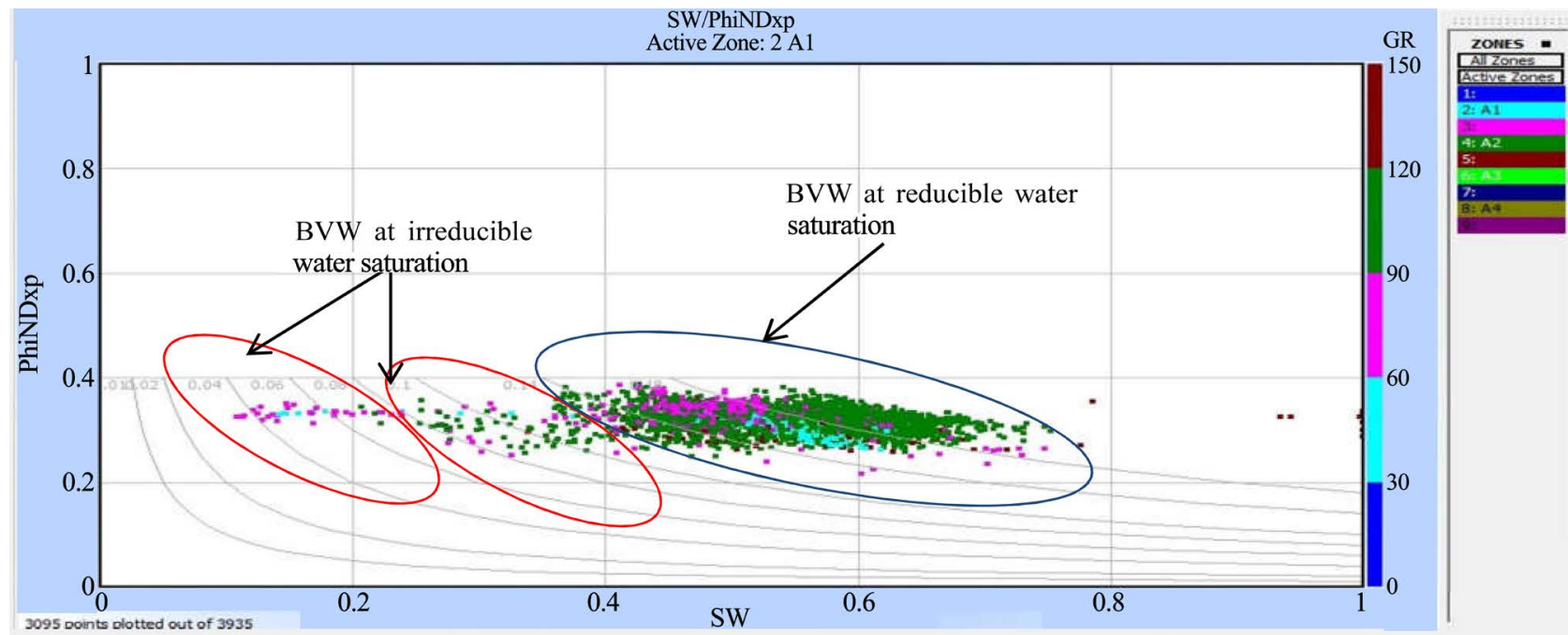

(a)

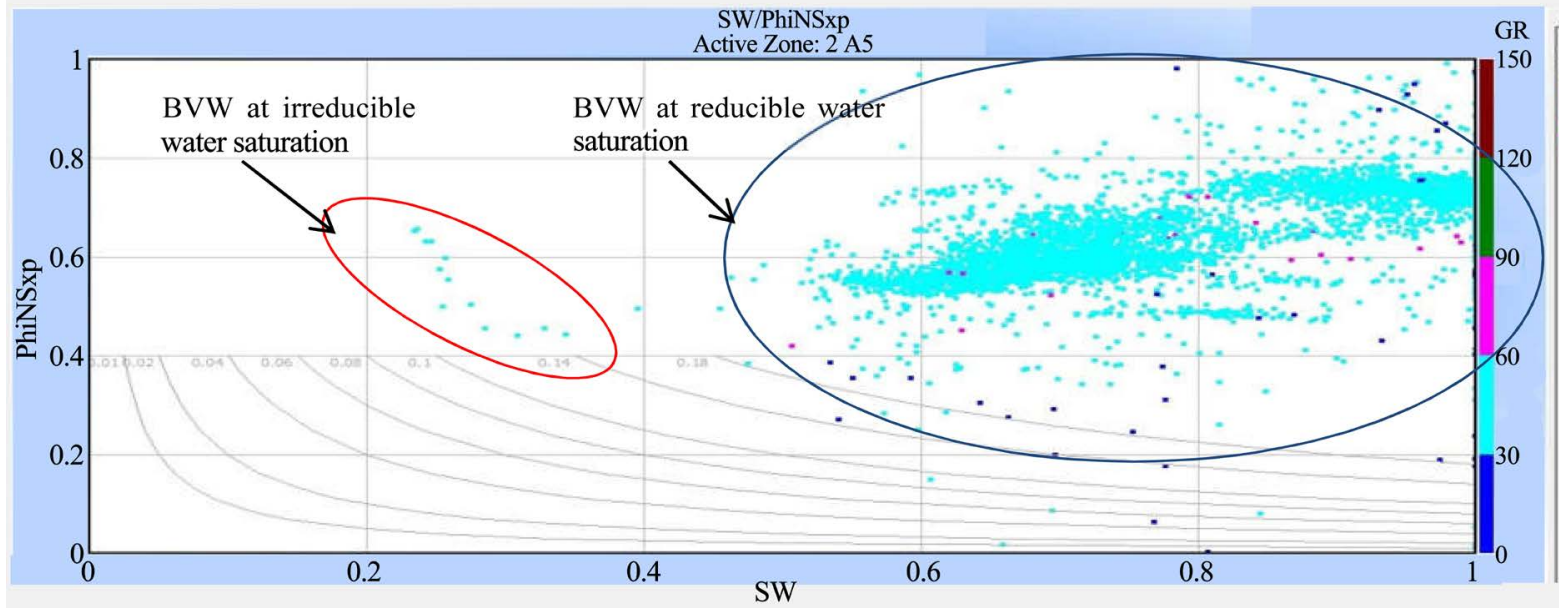

(b)

Figure 10. Buckle plots of water saturation against porosity in determining BVW and irreducible water saturation for A well A3 and B well A4. 

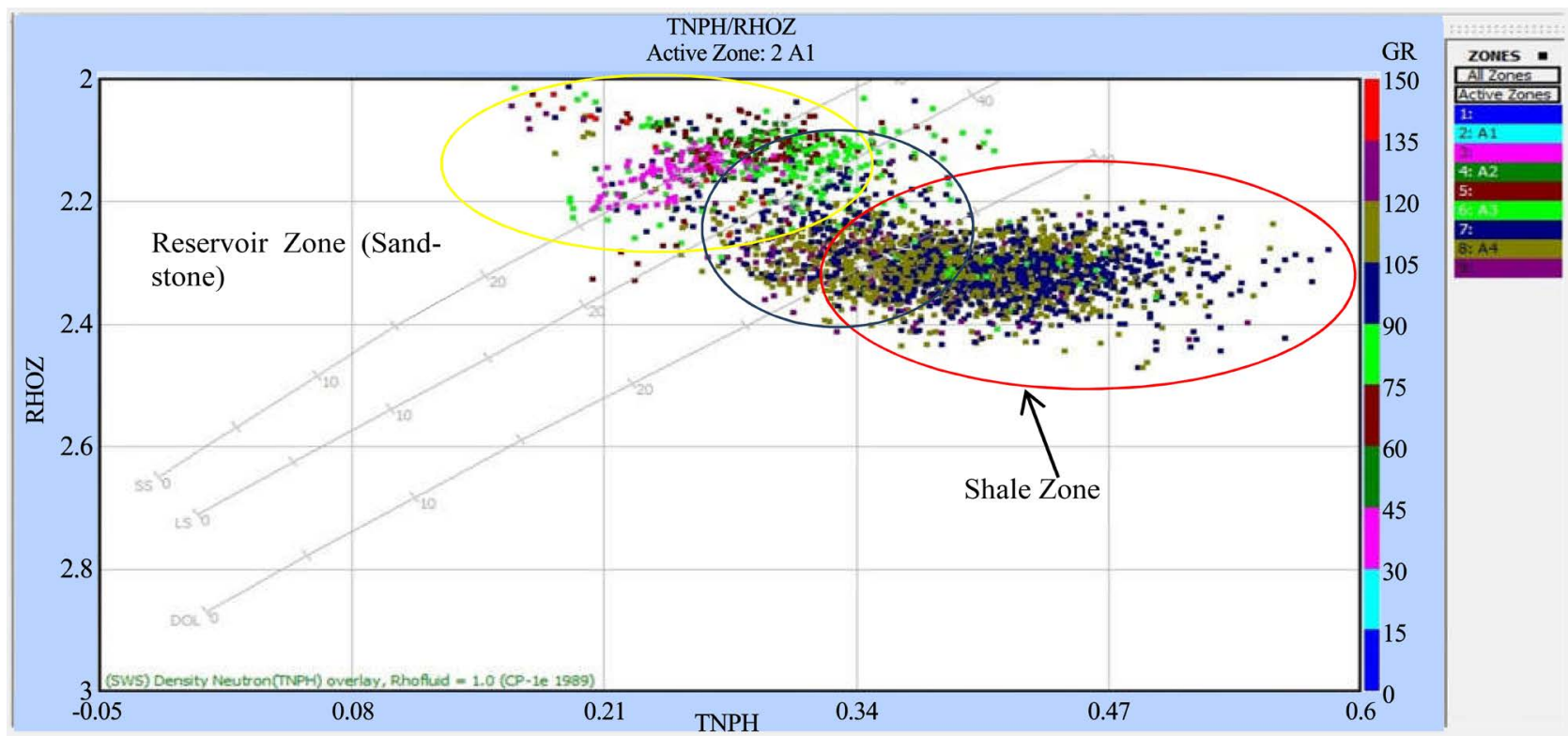

(a)

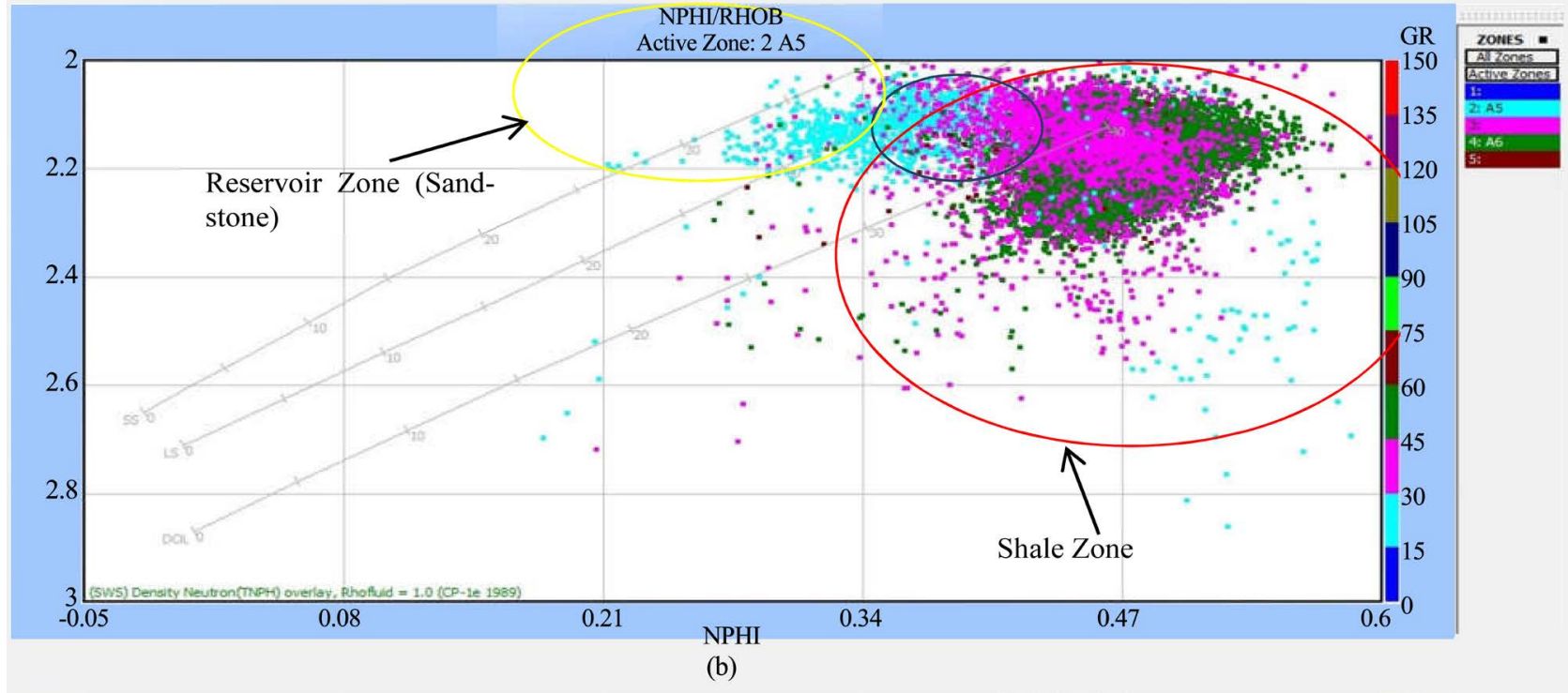

Figure 11. Lithological identification of rocks in the studied wells at K-Field. With (A) Well A3 and (B) A4.

exists within the "hydrocarbon window". Petrophysical properties especially permeability are also sensitive to sedimentological controls. Porosity values are good in shoreface and channels deposits but they drop by an average of $10 \%$ to floodplain. Average permeability values are $10 \%$ to $15 \%$ higher in channels and shoreface than floodplain deposits. Areas of higher porosity and permeability in shoreface, channels and delta plain zones are located to the south of Bomana, gradually deteriorating to the northeast where flood plain deposits predominate. In the Bomana area, the sequence 3 is dominated by very fine shoreface and Delta plain sands with the floodplain restricted to the north in mostly sequence 4 and 5. The best reservoir quality unit, grading to the shoreface, channels and delta plain are deposited to the southeast section of the field thus showing a con- 
sistence direction of reservoir quality which tie with direction of depositional environment.

\section{Acknowledgements}

The author acknowledges the Pan African University (PAU) Through African Union and African Development Bank for financial support. The authors thank SNH (National Hydrocarbons Cooperation in Cameroon) who kindly provided the data set used in this study and granted permission to publish this article.

\section{Conflicts of Interest}

The authors declare no conflicts of interest regarding the publication of this paper.

\section{References}

[1] Coughlin, R.M., Bement, W.O. and Maloney, W.V. (1993) Petroleum Geology of the Deltaic Sequence, Rio del Rey Basin, Offshore Cameroon. AAPG International Conference and Exhibition, The Hague, 17-20 October 1993.

[2] SNH (2010) Republic of Cameroon, Third Liscencing Round: The Rio Del Rey Basin Basin. 4-8.

[3] Allen, J.R.L. (1970) Sediments of the Modern Niger Delta, a Summary and Review. In: Morgan, J.P. and Shaver, R.H., Eds., Deltaic Sedimentation, Modern and Ancient, Vol. 15, SEPM Special Publication, Tulsa, 138-151. https://doi.org/10.2110/pec.70.11.0138

[4] Allen, J.R.L. (1965) Late Quaternary Niger Delta and Adjacent Areas: Sedimentary Environments and Lithofacies. American Association of Petroleum Geologist Bulletin, 49, 547-600.

[5] Doust, H. and Omatsola, E. (1990) Niger Delta. In: Edwards, J.D. and Santogrossi, P.A., Eds., Divergent/ Passive Margin Basins: AAPG Memoir 48, 239-248.

[6] Haack, R.C., Sundararaman, P., Diedjomahor, J.O., Xiao, H., Gant, N.J., May, E.D. and Kelsch, K. (2000) Niger Delta Petroleum Systems. Nigeria. In: Mello, M.R. and Katz, B.J., Eds., Petroleum Systems of South Atlantic Margins. American Association of Petroleum Geologist Memoir, Vol. 73, 213-231.

[7] Corredor, F., Shaw, J.H. and Bilotti, F. (2005) Structural Styles in the Deep-Water Fold and Thrust Belts of the Niger Delta. Aapg Bulletin, 89, 753-780. https://doi.org/10.1306/02170504074

[8] SNH (2014) Blocks on Offer in the Rio Del Rey, Douala/Kribi-Campo and Mamfe Basin.

[9] Vail, P.R. (1987) Seismic Stratigraphy Interpretation Procedures. In: Bally, A.W., Ed., Atlas of Seismic Stratigraphy, AAPG Studies in Geology, Vol. 1, No. 27, 1-10.

[10] Van Wagoner, J.C., Mitchum, R.M., Campion, K.M. and Rahmanian, V.D. (1990) Siliciclastic Sequence Stratigraphy in Well Logs, Cores, and Outcrops. AAPG Methods in Exploration Series, 7, 55.

[11] Blin, B. and Ugolini, J.M. (2000) Cameroon-Basin du Rio Del Rey: Synthesis geo-petroliere Elf Serepca 341-DE No 2000/3/00401/BB.

[12] Galloway, W.E. (1989) Genetic Stratigraphic Sequences in Basin Analysis I: Architecture and Genesis of Flooding-Surface Bounded Depositional Units. AAPG Bulle- 
tin, 73, 125-142.

[13] Ellis, D.V. and Singer, J.M. (2007) Well Logging for Earth Scientists (Vol. 692). Springer, Dordrecht. https://doi.org/10.1007/978-1-4020-4602-5

[14] Rider, M. (1986) The Geological Interpretation of Well Logs. Blackie, Glasgow, 151-165.

[15] Asquith, G. and Krygowski, D. (2004) Basic Well Log Analysis. American Association of Petroleum Geologists, Tulsa.

[16] Njoh, O.A. and Taku, A.J. (2016) Shallow Marine Cretaceous Sequences and Petroleum Geology of the Onshore Portion Rio del Rey Basin, Cameroon, Gulf of Guinea. Open Journal of Marine Science, 6, 177. https://doi.org/10.4236/ojms.2016.62014

[17] Morris, R.C. (1971) Stratigraphy and Sedimentology of Jackfork Group, Arkansas. AAPG Bulletin, 55, 387-402. 